\title{
Population biology of bay anchovy Anchoa mitchilli in the mid Chesapeake Bay
}

\author{
T. A. Newberger ${ }^{1}$, E. D. Houde ${ }^{2, *}$ \\ ${ }^{1}$ Marine Science Institute, University of California, Santa Barbara, California 93106, USA \\ ${ }^{2}$ The University of Maryland System, Center for Environmental and Estuarine Studies, Chesapeake Biological Laboratory, \\ PO Box 38, Solomons, Maryland 20688, USA
}

\begin{abstract}
The population biology of bay anchovy Anchoa mitchilli was studied from July 1986 to December 1987 to estimate relative abundance, age structure, growth and mortality. Trawl surveys indicated that mean abundance, indexed by catch-per-unit-effort (CPUE), was higher in the JulyNovember period in 1986 than in 1987. Mean CPUE was highest in September of each year when catches were dominated by recruiting, young-of-the-year (YOY) anchovy. Annuli on otoliths indicated the presence of 4 age classes. Maximum age was $3+$, when some individuals were $85 \mathrm{~mm}$ fork length (FL) and $>5 \mathrm{~g}$ wet wt. The population consisted primarily of YOY and age $1+$ individuals. Observed lengths-at-age were highly variable. Although most growth in length was completed by age $1+$, significant increases in length and, especially, weight occurred in older fish. The parameters of a von Bertalanffy growth model, fitted to the means of back-calculated lengths at otolith annuli and fall marks, are: $L_{\infty}=129.3 \mathrm{~mm}$ FL, $K=0.23$, and $t_{0}=-1.23 \mathrm{yr}$. The best estimates of mean fork length-at-age were generated by a seasonally oscillating version of the von Bertalanffy model, with $L_{\mathrm{c}}=107.0 \mathrm{~mm}$ FL, $K=0.36$ and $t_{0}=-0.81 \mathrm{yr}$. Fork lengths-at-age, based upon this model, are: age 1, $50.4 \mathrm{~mm}$; age 2,67.6 mm; and age $3,79.5 \mathrm{~mm}$. The instantaneous natural mortality rates of recruited anchovy are high. Annual mortality rates, estimated from catch curve analyses, ranged from 2.2 to 2.9 ( 89 to $95 \% \mathrm{yr}^{-1}$ ). The fast growth and high mortality rates indicated that maximum cohort biomass is achieved during the late postlarval or early juvenile period.
\end{abstract}

KEY WORDS: Anchovy · Anchoa mitchilli $\cdot$ Chesapeake Bay · Population biology

\section{INTRODUCTION}

The bay anchovy Anchoa mitchilli (Engraulidae) is the most abundant fish in the Chesapeake Bay and possibly in the coastal, western North Atlantic (Hildebrand \& Schroeder 1928, Morton 1989, Houde \& Zastrow 1991). It lives over the continental shelf and in coastal bays and estuaries from the Gulf of Maine to Brazil (Hildebrand 1963, Hoese \& Moore 1977). This small planktivore, which rarely exceeds $100 \mathrm{~mm}$ total length (Hildebrand \& Schroeder 1928), is not exploited commercially but is preyed upon by commercially important species, including weakfish, striped bass, bluefish and summer flounder (Schaefer 1970, Mer-

- Addressee for correspondence riner 1975, Richards 1976, Homer \& Boynton 1978, Hartman 1993). The bay anchovy is a major trophic link in estuarine food chains through its role in converting planktonic biomass into forage for piscivorous fishes (Hildebrand \& Schroeder 1928, Baird \& Ulanowicz 1989).

Bay anchovy population growth, mortality rates, age structure and maximum age are poorly known but essential to understand its trophic role. Its reproductive biology recently has been studied in the mid (Zastrow et al. 1991) and lower Chesapeake Bay (Luo \& Musick 1991). Aspects of its biology were studied in Delaware Bay (Stevenson 1958, PSEG 1984). Vouglitois et al. (1987) discussed its seasonal abundance, distribution and life history in Barnegat Bay, New Jersey. Recent studies in Chesapeake Bay have focused on food, feeding, and bioenergetics of bay anchovy (Vazquez 1989, 
Klebasko 1991, Luo \& Brandt 1993) to elucidate the role of this key species in the Bay ecosystem. Many reports on bay anchovy abundance are included in fish survey literature and synopses of its biology have been published (Monaco et al. 1989, Morton 1989, Houde \& Zastrow 1991).

Objectives of this study were to: (1) develop methodology to age bay anchovy; (2) determine population age structure and sex ratios; (3) determine size-at-age, growth rates and recruitment patterns; (4) develop growth models; and (5) estimate mortality rates.

\section{METHODS}

Field collections. 1986: Collections were made weekly at Stn 5 (Fig. 1) from July to September, twice in October and once in November. Additional samples were ob-

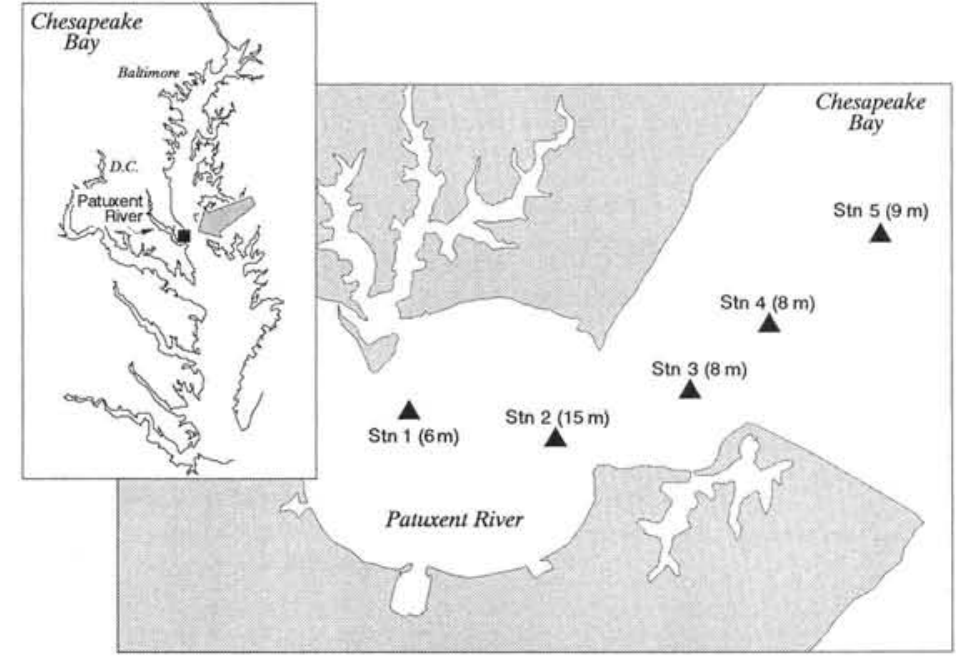

Fig. 1. Anchoa mitchilli. Sampling stations and depths in the Chesapeake Bay, USA, and mouth of the Patuxent River where bay anchovy were collected

1987: Sampling effort was expanded in 1987 to examine onshore and offshore sites for possible CPUE differences. Weekly sampling was carried out on a 5 station transect (Fig. 1) from June to September. Samples were obtained twice monthly in April, May and October and monthly in February, March and December. Because anchovies were rare at our stations during winter, additional trawl samples were collected

Table 1. Anchoa mitchilli. Summary of bay anchovy catch data for 1986 and 1987, giving the mean catch-per-unit-effort (CPUE), number of trawls (n), and standard deviation (SD) of CPUE by month and station. Each standard collection was a 10 min tow of a $4.9 \mathrm{~m}$ semi-balloon trawl. Station locations are given in Fig. 1

\begin{tabular}{|c|c|c|c|c|c|c|c|c|c|c|c|c|c|c|c|}
\hline Month & $\mathrm{n}$ & $\begin{array}{c}\text { Stn } 1 \\
\text { CPUE }\end{array}$ & SD & $\mathrm{n}$ & $\begin{array}{l}\text { Stn } 2 \\
\text { CPUE }\end{array}$ & SD & $\mathrm{n}$ & $\begin{array}{l}\text { Stn } 3 \\
\text { CPUE }\end{array}$ & SD & $\mathrm{n}$ & $\begin{array}{l}\text { Stn } 4 \\
\text { CPUE }\end{array}$ & SD & $\mathrm{n}$ & $\begin{array}{l}\text { Stn } 5 \\
\text { CPUE }\end{array}$ & SD \\
\hline \multicolumn{16}{|l|}{1986} \\
\hline Jul & 0 & & & 0 & & & 0 & & & 0 & & & 32 & 159.8 & 196 \\
\hline Aug & 0 & & & 0 & & & 0 & & & 0 & & & 14 & 328.8 & 503 \\
\hline Sep & 4 & 954.3 & 1131 & 4 & 28.0 & 41 & 4 & 11.0 & 13 & 0 & & & 8 & 1024.5 & 1001 \\
\hline Oct & 0 & & & 0 & & & 0 & & & 0 & & & 4 & 146.5 & 121 \\
\hline Nov & 0 & & & 0 & & & 0 & & & 0 & & & 5 & 110.6 & 204 \\
\hline$\sum \mathrm{n}, \bar{x}$ CPUE & 4 & 954.3 & & 4 & 28.0 & & 4 & 11.0 & & 0 & & & 63 & 302.4 & \\
\hline \multicolumn{16}{|l|}{1987} \\
\hline Feb & 0 & & & 0 & & & 0 & & & 0 & & & 2 & 4.0 & 4 \\
\hline Mar & 0 & & & 0 & & & 0 & & & 0 & & & 2 & 26.0 & 20 \\
\hline Apr & 2 & 156.0 & 156 & 2 & 0.0 & & 2 & 1.5 & 2 & 2 & 1.0 & 1 & 5 & 19.2 & 27 \\
\hline May & 2 & 84.0 & 80 & 2 & 8.0 & 4 & 2 & 14.0 & 14 & 2 & 47.0 & 43 & 4 & 31.5 & 52 \\
\hline Jun & 8 & 27.1 & 52 & 4 & 0.8 & 1 & 5 & 18.8 & 28 & 4 & 40.0 & 61 & 17 & 19.6 & 25 \\
\hline Jul & 4 & 21.0 & 36 & 4 & 0.0 & - & 4 & 124.0 & 140 & 4 & 0.8 & 1 & 14 & 95.8 & 252 \\
\hline Aug & 3 & 0.0 & - & 3 & 0.0 & - & 3 & 128.3 & 181 & 3 & 3.0 & 4 & 13 & 13.8 & 32 \\
\hline Sep & 5 & 8.2 & 15 & 5 & 1.6 & 3 & 5 & 150.2 & 295 & 3 & 54.7 & 46 & 10 & 129.4 & 159 \\
\hline Oct & 2 & 0.0 & - & 2 & 0.5 & 0.5 & 2 & 77.5 & 78 & 1 & 0.0 & - & 4 & 28.0 & 30 \\
\hline Nov & 1 & 0.0 & - & 1 & 15.0 & - & 1 & 0.0 & - & 1 & 119.0 & - & 2 & 3.0 & 3 \\
\hline Dec & 1 & 0.0 & - & 1 & 0.0 & - & 1 & 0.0 & - & 1 & 0.0 & - & 2 & 0.0 & 0 \\
\hline$\sum \mathrm{n}, \bar{x}$ CPUE & 28 & 29.4 & & 24 & 1.8 & & 25 & 76.5 & & 21 & 26.3 & & 75 & 47.3 & \\
\hline
\end{tabular}


farther offshore in February and March 1987 at a $30 \mathrm{~m}$ deep site, $4 \mathrm{~km}$ east of Stn 5 . Those samples were utilized in age and growth analyses.

Anchovies were collected in a $4.9 \mathrm{~m}$ semi-balloon trawl with a $3 \mathrm{~mm}$ stretched-mesh cod-end liner. Ten minute tows were made at mid depth at 2 to 3 knots vessel speed. Two tows were made at Stn 5, our intensively sampled station (Fig. 1), on each sampling date, but single tows were made at other stations. Anchovies were fixed and preserved immediately in $10 \%$ buffered formalin. After $2 \mathrm{~d}$ they were drained, soaked in fresh water for $2 \mathrm{~h}$ and transferred to $70 \%$ ethanol for storage.

Laboratory procedures. Fork length (FL, $\mathrm{mm}$ ), wet weight $(\mathrm{g})$, and sex were determined from randomly drawn subsamples of approximately 100 preserved anchovies from each catch. Length and weight measurements were not adjusted for possible preservativeinduced shrinkage. Five pairs of sagittal otoliths were extracted from fish in each represented $5 \mathrm{~mm}$ length class on each collection date to ensure that otoliths were obtained from all length classes in the collections. This procedure did not insure that aged individuals were represented proportionally with respect to their abundance in the catches. Fewer otoliths were examined from 1986 than from 1987 collections because fewer samples were available in 1986 and because otolith degradation of some poorly preserved samples was problematical in 1986.

Otoliths were examined under a stereomicroscope with reflected light at $37.5 \times$ to $75 \times$ magnification. Under these conditions opaque zones (summer growth) appeared white and hyaline zones (winter growth) appeared black. An annual increment is composed of an inner opaque and an outer hyaline zone (Fig. 2). We defined the otolith annulus as the interface between a hyaline and an opaque zone, i.e the inner boundary of each opaque zone, following Fitch (1951). We defined a fall mark (Fig. 2) as the interface between an opaque and hyaline zone, i.e. the inner boundary of each hyaline zone. We found that, on average, hyaline zones began to form in mid October and opaque zones began to form in mid May. Otolith measurements were made from the focus to each annulus, fall mark, and otolith edge along the rostral radius.

Marginal increment analysis of otolith measurements from 277 age $1+$ anchovy was used to validate annuli (Bagenal \& Tesch 1978, Beamish \& McFarlane 1983). A marginal increment is the distance from the outermost apparent annulus to the otolith edge (Fig. 2). If it is a true annulus, the width of the marginal increments on seasonally collected otoliths should be minimal once each year, immediately after annulus formation.
Data analyses. CPUE (number per 10 min trawl tow) data were $\log _{10}$-transformed. Means were calculated for station, month, year and combined years. Possible differences in mean $\log _{10}(\mathrm{CPUE}+1)$ between years and months were tested in a 2-way ANOVA, followed by a Student-Newman-Keuls (SNK) multiple range test. Possible deviations from a hypothesized 1:1 sex ratio for monthly collections were tested in a chisquared homogeneity test.

Weight-length relationships were described by a power equation $\left(W=a L^{b}\right)$. Analysis of covariance, with length as the covariate, was applied to test for differences in the allometric relationships (slopes and intercepts of the regression equations) between sexes and among seasons. Fulton's condition factor $(C$; Ricker 1975), an index of relative condition, was calculated from the weight-length data as $C=W / L^{3}$. Fulton's index was judged to be appropriate for the comparative condition analysis because length ranges of anchovy which were being compared were similar among seasons and years (Table 2). A 2-way ANOVA and the SNK multiple comparisons procedure were used to test for differences in condition between seasons and sexes.

The relationship between FL and otolith radius (OR) was described by linear regression on the combined data from males and females because we found no significant difference between sexes in this relationship. The FL-OR relationship was applied in a 'body-proportional' procedure (Francis 1990) to back-calculate anchovy FL from otolith measurements at annuli and fall marks. Other back-calculation procedures, including a regression method and the Fraser-Lee method (Carlander 1981), were tested in preliminary analyses and gave nearly identical mean back-calculated lengths-at-age.

To account for age variability within a year class that was associated with differing capture dates, ages at date

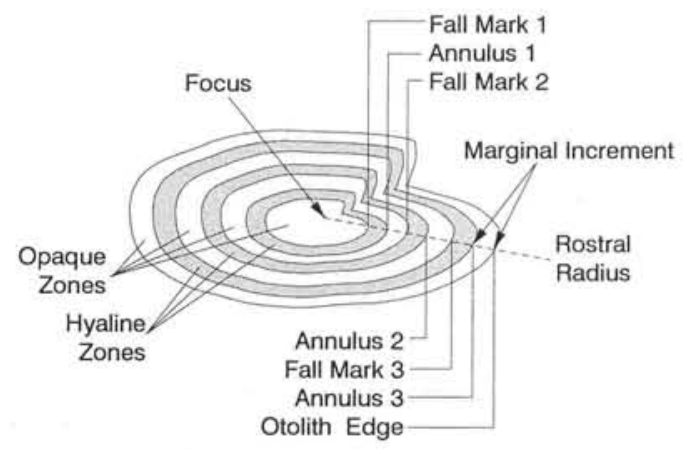

Fig. 2. Anchoa mitchilli. Diagram of an otolith from an age $3+$ bay anchovy, indicating the rostral radius, focus, annuli, fall marks and marginal increment. Light bands represent opaque 'summer-growth' zones and dark bands represent hyaline 'winter growth' zones 
Table 2. Anchoa mitchilli. Coefficients $(a, b)$, number of fish examined (n) and summary statistics of the weight-length relationship $\left(W=a L^{b}\right)$ of bay anchovy by seasons, 1986 and 1987. Mean Fulton condition factors and standard deviations also are given. Season 1: winter (December, January, February); Season 2: spring (March, April, May); Season 3: summer (June, July, August); Season 4: fall (September, October, November)

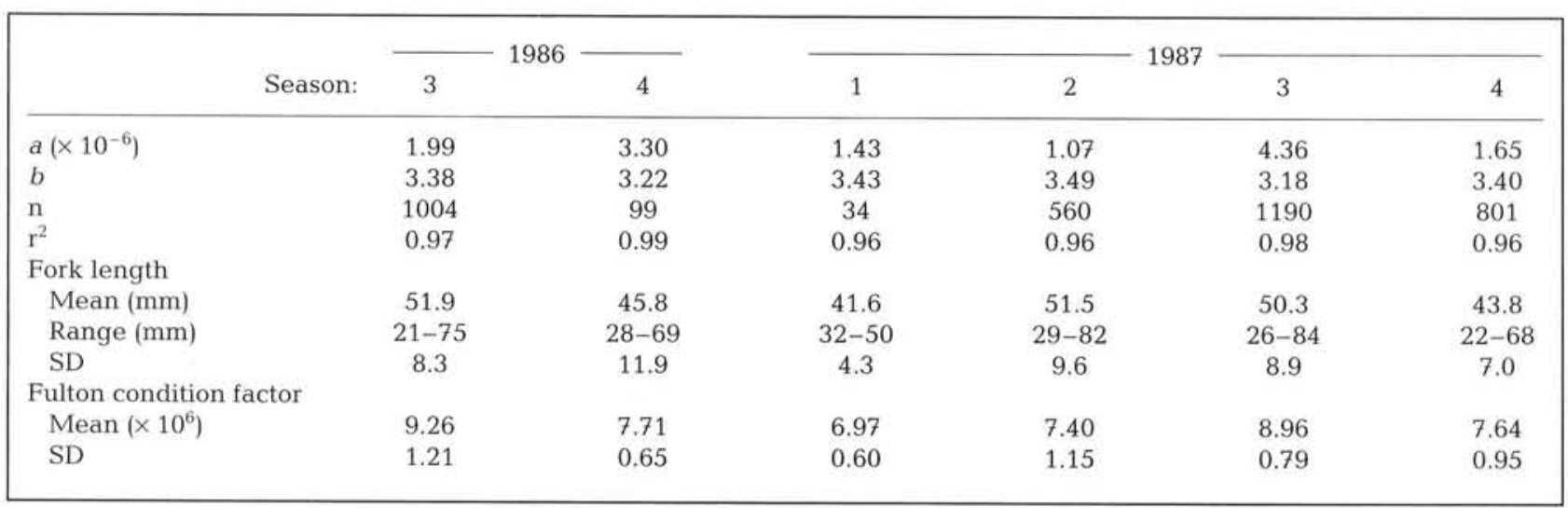

of collection were adjusted to estimate actual age to the nearest $0.01 \mathrm{yr}$. The adjustment procedure was based on knowledge of peak spawning date (Dalton 1987) and our estimate of the dates of otolith annulus formation. Based on a mean hatching date of 15 July and a mean annulus formation date of 15 May, fractions of years were either added to or subtracted from the number of otolith annuli of individuals to estimate age. For example, the adjusted age of an anchovy with 2 annuli collected on 15 June would be 1 mo less than 2 yr old (i.e. $1.92 \mathrm{yr}$ ). This procedure did not adjust ages for variability resulting from protracted spawning, a problem that is proportionally greater in aging YOY anchovy. Zastrow et al. (1991) overcame this problem by counting daily otolith increments in YOY bay anchovy. Their results are compared with those from our analysis.

Growth. Lengths- and weights-at-age were estimated from fitted von Bertalanffy growth models (VBGF). The models were fitted (1) to the means of back-calculated lengths-at-annuli and fall marks, and (2) to the observed lengths-at-adjusted age. The equation for the VBGF (Ricker 1975) is:

$$
L_{t}=L_{\infty}\left(1-\mathrm{e}^{-K\left(t-t_{0}\right)}\right)
$$

where $L_{t}$ is the estimated length-at-age, $L_{\infty}$ is the mean asymptotic length, $K$ is the growth coefficient, $t_{0}$ is the hypothetical age at which a fish would have been zero length had it always grown according to the model, and $t$ is age.

Non-linear least-squares procedures were used to fit the models. All growth models were fitted to pooled data from bay anchovy collected in 1986 and 1987. Weight forms of the VBGF also were fitted to data, by converting lengths to weights using the mean exponential coefficient from the bay anchovy weight-length relationship:

$$
W_{t}=W_{\infty}\left(1-\mathrm{e}^{-K\left(t-t_{0}\right)}\right)^{b}
$$

where $b$ is the mean exponent (3.375) from the 1987 weight-length relationship, $W_{t}$ is the estimated weightat-age, and $W_{\infty}$ is the mean asymptotic weight.

Inspection of the mean lengths-at-age data suggested that growth was strongly seasonal. Consequently, a seasonally oscillating version of the VBGF (Pauly \& Gaschutz 1979, Hanumara \& Hoenig 1987) was fitted by an iterative, non-linear procedure to the means of data on back-calculated lengths-at-annuli and fall marks. This model is:

$$
L_{t}=L_{\infty}\left(1-\mathrm{e}^{-K\left(t-t_{0}\right)+\frac{c K}{2 \pi} \sin \left[2 \pi\left(t-t_{s}\right)\right]}\right)
$$

where $c$ determines the amplitude of oscillations and $t_{s}$ is the age at which oscillations begin.

Estimates of sizes-at-age from this model were compared with estimates from the standard VBGF model.

Abundance-at-age and mortality. The relative abundances-at-age from CPUE data were estimated from length distributions of otolith-aged anchovies grouped by $5 \mathrm{~mm}$ FL intervals. The estimates were obtained for the biweekly catches. Ages were assigned to observed lengths using an age-length key developed from the length-frequency and otolith-aging data based upon normal probability statistics (Zar 1974). Instantaneous mortality rates were estimated by catch curve analysis (Ricker 1975) as the decline in relative abundances-atage in which the relationship between abundance and age was described by a negative exponential model. Abundance-at-age data were derived from aggregated monthly abundances (Table 1) partitioned into age groups. Different assumptions regarding vulnera- 
bility of bay anchovy to the trawl and an alternative age-group aggregating assumption were made to determine sensitivity of mortality estimates. Also, empirically derived models that incorporate lifehistory information (Ssentongo \& Larkin 1973, Pauly 1980, Hoenig 1983, Roff 1984) were applied to our bay anchovy data as alternative methods to estimate mortality rates.

\section{RESULTS}

\section{Catch analysis}

A total of 30782 bay anchovies were collected in 252 trawl tows, giving a mean CPUE of 122.2 anchovies per tow. Monthly CPUE data are summarized in Table 1. At the intensively sampled Stn 5, during the comparable July to November periods, the 1986 CPUE $(302.4)$ was significantly higher than that in $1987(68.2)$ (ANOVA, p < 0.002). The highest catches at Stn 5 were made in September of each year.

From July to November, the CPUE at Stn 5 varied several-fold among months in 1986 and 1987 (Table 1). In 1986, monthly mean CPUEs did not differ significantly (ANOVA, $p>0.30$ ). In 1987, monthly mean CPUEs did differ significantly (ANOVA, p $<0.05$ ), although the means that were significantly different could not be identified unambiguously in an a posteriori multiple range test $(\mathrm{SNK}, \mathrm{p}>0.05)$.

\section{Recruitment}

Significant numbers of YOY bay anchovy were collected first in late July 1986 and in mid July 1987. Anchovies $<25-30 \mathrm{~mm}$ FL were not fully retained by the trawl cod-end, but their occurrence in catches indicated that recruitment of YOY anchovy began earlier in 1987 than in 1986. New recruits dominated catches from August to October 1986 and August to November 1987 (Fig. 3). During those months YOY anchovy represented $85 \%$ of the total catch in 1986 and $84 \%$ in 1987.

Recruitment in mid Chesapeake Bay apparently was higher in 1986 than in 1987 (Fig. 3). The mean abundances of YOY in September, the peak month of recruitment, were 928 and 109 per tow in 1986 and 1987 , respectively.

Length-frequency distributions were multimodal in 1986 and 1987 (Fig. 4). From July through October, the modes clearly delineated age groups, distinguishing YOY recruits $(<45 \mathrm{~mm} \mathrm{FL})$ from age $1+$ and older anchovies. Modes representing the YOY and age 1+ fish were most prominent. The first YOY recruits

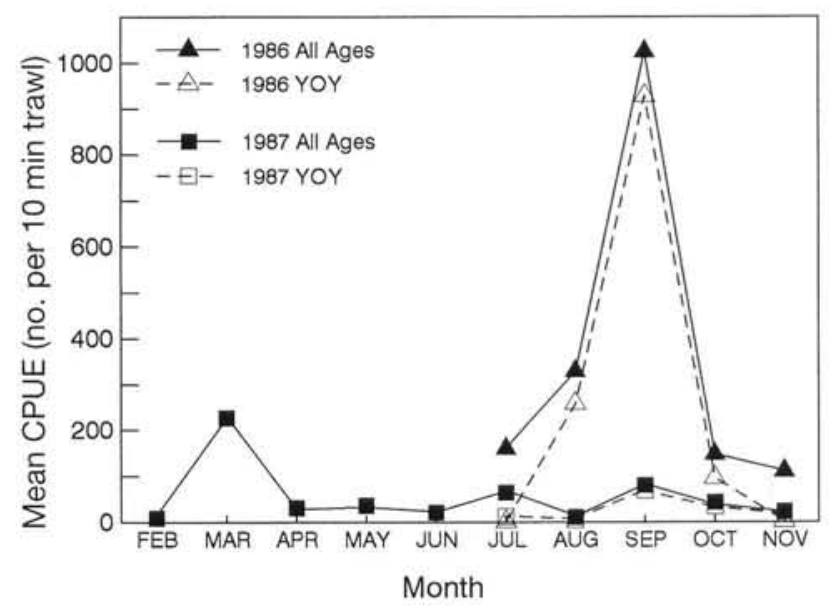

Fig. 3. Anchoa mitchilli. Mean catch-per-unit-effort (CPUE) of bay anchovy from 1986 and 1987 collections, averaged over all stations in each year. Total catches and catches of youngof-the-year (YOY) anchovy are indicated

( $<40 \mathrm{~mm} \mathrm{FL)} \mathrm{were} \mathrm{observed} \mathrm{each} \mathrm{year} \mathrm{in} \mathrm{the} 15$ to 31 July catches.

\section{Sex ratio}

Females were most abundant. The mean female to male ratio for 4048 anchovies that were examined was $1.16(53.7 \%$ females). The mean sex ratios in 1986 (1.13 females per male) and 1987 (1.17 females per male) differed significantly from $1.0\left(\chi^{2}, p<0.05\right)$.

\section{Weight-length relationship}

For the combined 1986 and 1987 data, there was no significant difference between sexes in the weightlength relationships (exponent $b$, ANCOVA, $\mathrm{p}>0.90$; intercept $a$, ANCOVA, p > 0.50). The weight-length relationships of the 1987 pooled data for males and females varied seasonally (Table 2), judging by differences in the exponents $(b$, ANCOVA, $\mathrm{p}<0.001)$. The SNK procedure indicated that the $b$ coefficients differed only between spring and summer and between summer and fall $(p<0.05)$. Because only summer and fall collections were represented in 1986, interannual comparisons were restricted to those 2 seasons. There was no indication that the exponents (b) differed significantly between 1986 and 1987 , but there were significant differences in the intercepts $(a$, ANCOVA, $\mathrm{p}<$ 0.05 ), suggesting that condition of bay anchovy differed between years.

Fulton's condition factor (Table 2) varied seasonally (ANOVA, p $<0.001$ ), probably in response to annual 


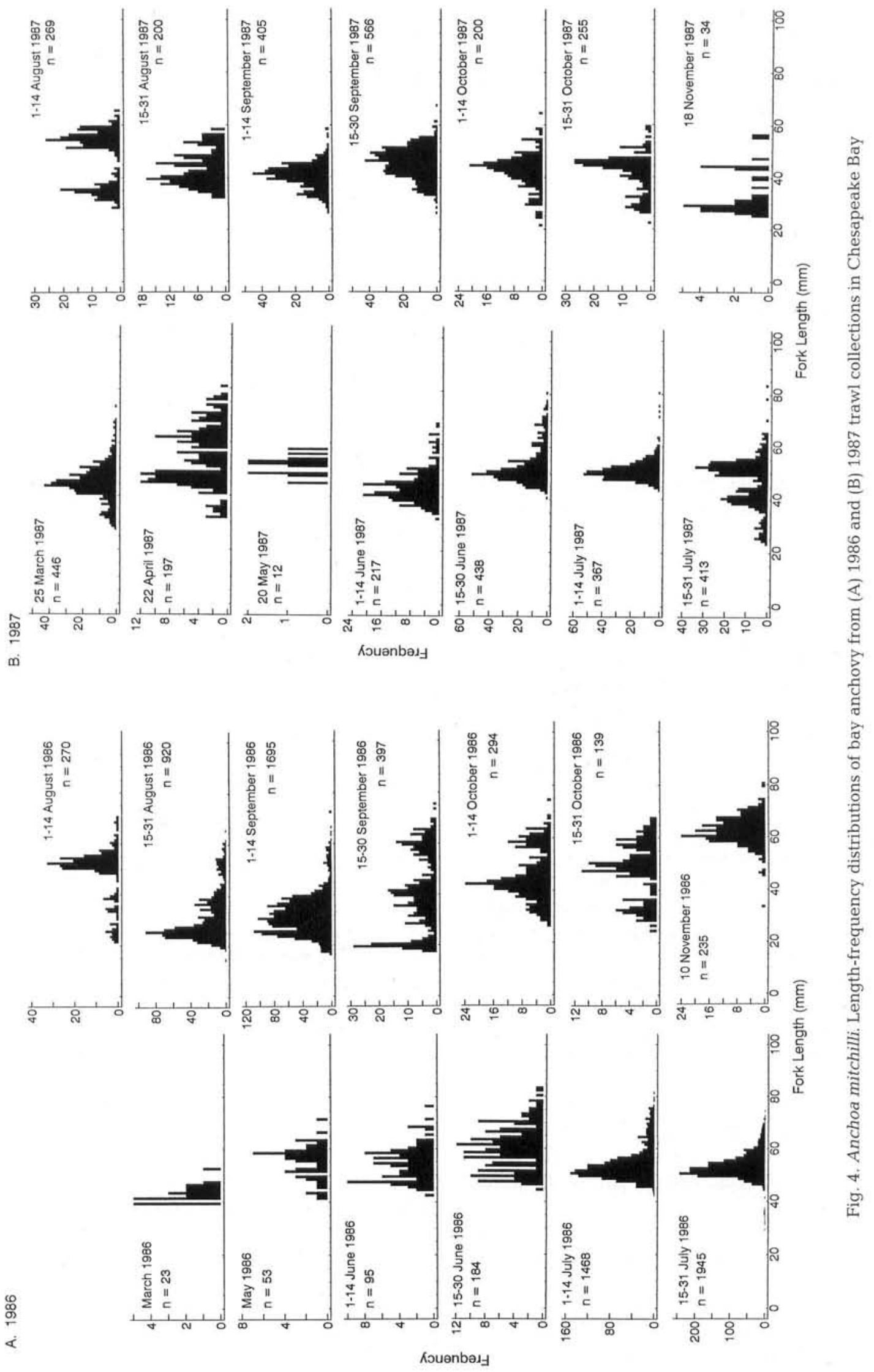


reproductive, growth and recruitment cycles. Condition was highest in summer and lowest in winter. Each of the seasonal mean condition factors in 1987 differed from all others (SNK, $\mathrm{p}<0.05)$. Condition did not differ between sexes (ANOVA, $\mathrm{p}>0.50$ ).

\section{Age and growth}

Annulus formation in bay anchovy occurred in mid May. Because minimal marginal increments on otoliths occurred only once per year, in the period mid May to early June (Fig. 5), the annuli were accepted as valid indicators of age.

The analysis of otoliths indicated that bay anchovy ranged from age $0+$ to $3+$. Age $3+$ individuals were uncommon. The age composition of the non-random sample of 863 otolith-aged anchovies was: 519 age $0+$, 296 age $1+, 44$ age $2+$, and 4 age $3+$. Otoliths from an additional 162 anchovies (16\%) were unreadable and not used in the aging analysis. The largest bay anchovy in our collections was $86 \mathrm{~mm}$ FL and $6.03 \mathrm{~g}$ wet wt, and could not be aged.

A linear model adequately described the relationship between fork length and otolith radius for 25 to $85 \mathrm{~mm}$ FL bay anchovy. Because there was no difference between sexes in slopes or intercepts of the relationships (ANCOVA, p > 0.70), a single model was used in back-calculations. The relationship is:

$$
L=10.06+51.26 R \quad r^{2}=0.94
$$

where $L$ is fork length $(\mathrm{mm})$ and $R$ is otolith radius $(\mathrm{mm})$.

At the end of the first summer's growth (fall mark 1), back-calculated lengths of age $0+$ fish ranged from 23 to $61 \mathrm{~mm} \mathrm{FL}$, with mean length equal to $39.1 \mathrm{~mm}$ (Table 3). The protracted spawning season was a major source of the variability in back-calculated lengths. The ranges of back-calculated lengths decreased with

Table 3. Anchoa mitchilli. Mean back-calculated fork lengths of bay anchovy at otolith annuli and at fall marks for pooled 1986-1987 samples. Also given are sample size (n), range, mean and standard deviation of back-calculated lengths

\begin{tabular}{|lcrrrr|}
\hline \multirow{2}{*}{ Otolith mark } & Age (yr) & \multicolumn{4}{c|}{ Back-calculated lengths (mm) } \\
& & $\mathrm{n}$ & Range & Mean & SD \\
\hline Fall mark 1 & 0.25 & 442 & $23-61$ & 39.1 & 7.1 \\
Annulus 1 & 0.83 & 322 & $26-65$ & 43.2 & 7.2 \\
Fall mark 2 & 1.25 & 96 & $47-74$ & 58.2 & 6.2 \\
Annulus 2 & 1.83 & 42 & $53-76$ & 64.7 & 6.1 \\
Fall mark 3 & 2.25 & 2 & $71-77$ & 74.0 & 3.0 \\
Annulus 3 & 2.83 & 2 & $73-79$ & 76.0 & 3.0 \\
\multicolumn{7}{c}{ Total: 906 } & & & \\
\hline
\end{tabular}

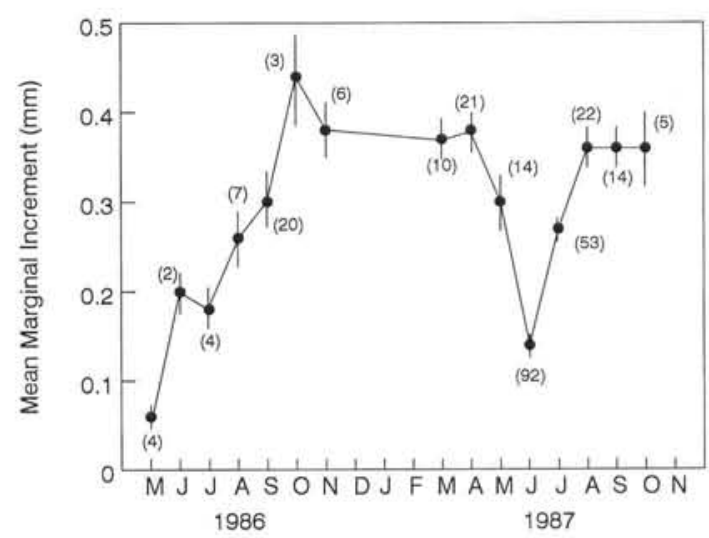

Fig. 5. Anchoa mitchilli. Mean monthly marginal increments on otoliths of bay anchovy from Chesapeake Bay. Sample sizes in parentheses. Vertical bars indicate $\pm 1 \mathrm{SE}$

age, partly because of small sample sizes, although growth compensation and size selective mortality may have occurred.

Fork lengths-at-age and weights-at-age, based upon the mean 1987 weight-length relationship, were estimated from fits of data to VBGF models. Results of fits to 3 versions of the model were similar (Table 4). The parameters of the VBGF model fitted to mean values of back-calculated lengths (Model A, Table 4) for combined years' data on lengths-at-annuli and fall marks (Table 3, Fig. 6) are: $L_{\infty}=129.3 \mathrm{~mm} \mathrm{FL}, K=0.23$, and $t_{0}=-1.23 \mathrm{yr}$. Lengths predicted by the model at ages 1 , 2 and 3 are longer than predicted lengths at annuli 1 , 2 and 3 because annulus formation occurs approximately 2 mo before the mean birth date. The VBGF model parameters fitted to data on observed fork lengths at adjusted ages (Model B, Table 4, Fig. 6) are: $L_{\infty}=138.0 \mathrm{~mm} \mathrm{FL}, K=0.21$, and $t_{0}=-1.34 \mathrm{yr}$.

An apparent seasonal pattern in growth (Fig. 6) caused VBGF Model A (Table 4) to considerably overestimate mean length at annulus 1 and caused smaller errors at older ages. For example, differences between

Table 4. Anchoa mitchilli. Predicted fork lengths (FL, mm) and wet weights (Wt, g) of bay anchovy from 3 von Bertalanffy growth models, based upon pooled 1986-1987 otolith data. Model A fitted to mean back-calculated lengths-at-annuli and fall marks. Model B fitted to observed lengths-at-age at annuli and fall marks. Model $\mathrm{C}$ fitted to mean back-calculated length data at annuli and fall marks with seasonal oscillations

\begin{tabular}{|lcrrrrrr|}
\hline \multirow{2}{*}{ Age (yr) } & \multicolumn{2}{c}{ A } & \multicolumn{2}{c}{ B } & \multicolumn{2}{c|}{ C } \\
& FL & Wt & FL & Wt & FL & Wt \\
\hline 1 & 51.9 & 1.27 & 53.7 & 1.42 & 50.4 & 1.25 \\
2 & 67.8 & 3.12 & 69.7 & 3.43 & 67.6 & 3.27 \\
3 & 80.4 & 5.55 & 82.7 & 6.10 & 79.5 & 5.60 \\
\hline
\end{tabular}




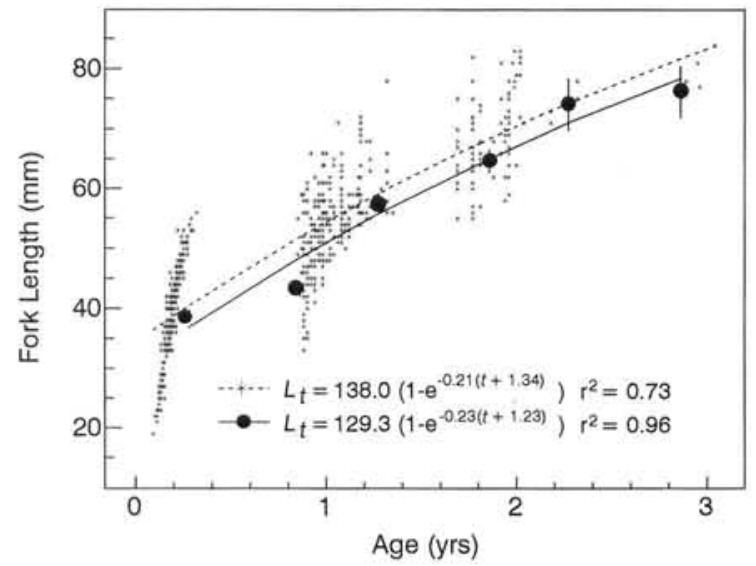

Fig. 6. Anchoa mitchilli. Length-at-age of bay anchovy from Chesapeake Bay and von Bertalanffy growth models fitted to (-) means of back-calculated fork lengths-at-annuli and atfall marks from pooled 1986 and 1987 data, and $(\cdot)$ observed fork lengths at adjusted ages

the lengths predicted by the VBGF back-calculation model (Model A, Table 4) and the mean back-calculated lengths (Table 3 ) ranged from $5.6 \mathrm{~mm}$ at annulus 1 (age $=0.83 \mathrm{yr}$ ) to $-2.8 \mathrm{~mm}$ at fall mark 3 (age $=$ $2.25 \mathrm{yr})$.

The seasonally oscillating VBGF Model C (Fig. 7), fitted to mean back-calculated lengths-at-age, gave better estimates. Its parameters are: $L_{\infty}=107.0 \mathrm{~mm} \mathrm{FL}, K=$ $0.36, t_{0}=-0.81 \mathrm{yr}, c=1.0$, and $t_{s}=0.04 \mathrm{yr}$. Differences between mean lengths predicted by this model and the mean back-calculated lengths (Table 3 ) ranged from $-1.4 \mathrm{~mm}$ at annulus 2 to $1.1 \mathrm{~mm}$ at annulus 1 .

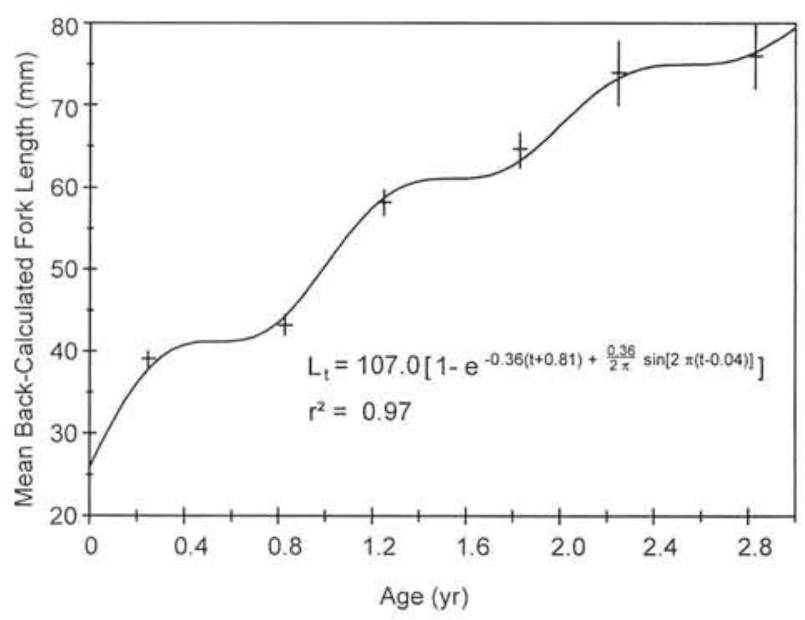

Fig. 7. Anchoa mitchilli. Mean back-calculated fork lengthsat-age of bay anchovy fitted to a seasonally oscillating von Bertalanffy growth model (Pauly \& Gaschutz 1979). Vertical bars indicate $\pm 1 \mathrm{SE}$
A growth-in-weight VBGF model, derived from the length-based, mean back-calculation results (Model A, Table 4) and the 1987 weight-length relationship, has parameter values $W_{\infty}=27.57 \mathrm{~g}, K=0.23, t_{0}=-1.23 \mathrm{yr}$ and $b=3.375$. Large increments in weight continued to be added throughout the lifespan of bay anchovy (Table 4). Estimated weights-at-age based upon the VBGF Models B and C, with $b=3.375$, were similar to the Model A results (Table 4).

Growth rate of YOY bay anchovy, calculated from the mean back-calculated length at fall mark 1 and the estimated time from hatching (15 July) until fall mark formation (15 October), was $0.41 \mathrm{~mm} \mathrm{~d}^{-1}$. YOY growth rates estimated from biweekly modal length progression of trawl-collected anchovy were $0.33 \mathrm{~mm} \mathrm{~d}^{-1}$ in 1986 and $0.20 \mathrm{~mm} \mathrm{~d}^{-1}$ in 1987 . Rates based on the modal progressions were lower because they did not include the relatively fast larval-stage growth that occurred before anchovy became vulnerable to the trawl.

\section{Mortality}

Estimated annual instantaneous mortality rates $(Z)$ from catch curves, under 2 different assumptions of vulnerability to the trawl, were 2.19 and 2.53 (Table 5), equivalent to 89 and $92 \%$ annual mortalities respectively. A third estimate from a catch curve, derived by pooling abundances of 3 mo age groups and assuming full vulnerability at age $0.5 \mathrm{yr}$ (Fig. 8), was $Z=2.95$, or $95 \% \mathrm{yr}^{-1}$. Four estimates from empirical models relat-

Table 5. Anchoa mitchilli. Annual mortality rate estimates for bay anchovy, derived from catch-curve analysis and from life history models

\begin{tabular}{|c|c|c|c|}
\hline \multirow[t]{2}{*}{ Method } & \multicolumn{3}{|c|}{ Mortality rates } \\
\hline & $\begin{array}{l}\text { Instantaneous } \\
\text { rate }(Z)\end{array}$ & SE & $\begin{array}{c}\text { Annual } \\
(\%)\end{array}$ \\
\hline Catch curve $1^{\text {a }}$ & 2.53 & 0.58 & 92 \\
\hline Catch curve $2^{\mathrm{b}}$ & 2.19 & 0.77 & 89 \\
\hline Catch curve $3^{c}$ & 2.95 & 0.95 & 95 \\
\hline Hoenig $(1983)^{d}$ & 1.42 & & 76 \\
\hline \multicolumn{4}{|l|}{ Ssentongo \& } \\
\hline Larkin $(1973)^{\mathrm{e}}$ & 1.09 & & 66 \\
\hline Pauly $(1980)^{t}$ & 0.63 & & 47 \\
\hline Roff $(1984)^{g}$ & 1.54 & & 79 \\
\hline \multicolumn{4}{|c|}{${ }^{a}$ Based on assumed fully recruited age $>0.5 \mathrm{yr}$} \\
\hline \multicolumn{4}{|c|}{${ }^{b}$ Based on anchovy $\geq 1.0 \mathrm{yr}$} \\
\hline \multicolumn{4}{|c|}{${ }^{\mathrm{c}}$ Anchovy grouped by 3 mo age intervals } \\
\hline \multicolumn{4}{|c|}{${ }^{\mathrm{d}}$ Relationship based on longevity } \\
\hline \multicolumn{4}{|c|}{ 'Relationship based on age structure } \\
\hline \multicolumn{4}{|c|}{$\begin{array}{l}\text { ' Relationship based on von Bertalanffy growth and tem- } \\
\text { perature parameters }\end{array}$} \\
\hline \multicolumn{4}{|c|}{$\begin{array}{l}{ }^{g} \text { Relationships based upon size and age at maturity, and } \\
\text { on von Bertalanffy growth parameters }\end{array}$} \\
\hline
\end{tabular}




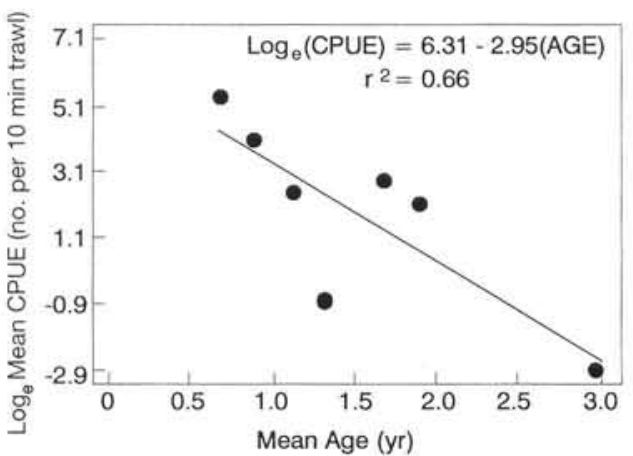

Fig. 8. Anchoa mitchilli. Catch-curve, based upon $\log _{e}$ (CPUEat-age) for bay anchovy collected during 1987 in Chesapeake Bay. CPUE data are for anchovy grouped into 3 mo age intervals. Full vulnerability to the trawl was assumed at age $0.5 \mathrm{yr}$

ing mortality to life-history traits (Table 5 ) were lower than the catch-curve estimates, ranging from $Z=0.63$ to 1.54 (i.e. 47 to $79 \% \mathrm{yr}^{-1}$ ).

\section{DISCUSSION}

\section{Interannual abundances}

CPUE data indicated that bay anchovy abundance in mid Chesapeake Bay was higher in 1986 than in 1987. Mean CPUE of YOY anchovy in September was nearly 10 times higher in 1986 than in 1987 although it is uncertain if baywide recruitment was higher in 1986 because our study was restricted to a small area. Data from a Maryland Department of Natural Resources (MD DNR 1990) $30 \mathrm{yr}$ seining survey in low-salinity tributaries have indicated more than 10 -fold interannual variability in bay anchovy abundances in Maryland waters (Fig. 9). This time series, based on tributaries in the northern half of the Bay, may depict abundance trends but it also could be biased because beach seine sampling is restricted to shallow littoral areas and low-salinity tributaries. The index value was approximately 4 times higher in 1986 than in 1987 (Fig. 9A), in general agreement with our CPUE estimates.

Abundance estimates of bay anchovy in 1969 to 1981 from monthly trawling at a site approximately $15 \mathrm{~km}$ north of our Stn 5 (Horwitz 1987) were not correlated (Kendall's tau, p > 0.99) with the MD DNR (1990) seining indices for the same years (Fig. 9). The trawl data varied less among years than did the seine data, except for the very low abundance estimate in 1976. Excluding 1976, mean annual CPUE from the trawl surveys varied less than 3 -fold among years. These trawl data may underrepresent anchovy abundances and variability because cod-end meshes ( $13 \mathrm{~mm}$ stretch-mesh) were too large to retain recruiting YOY individuals.

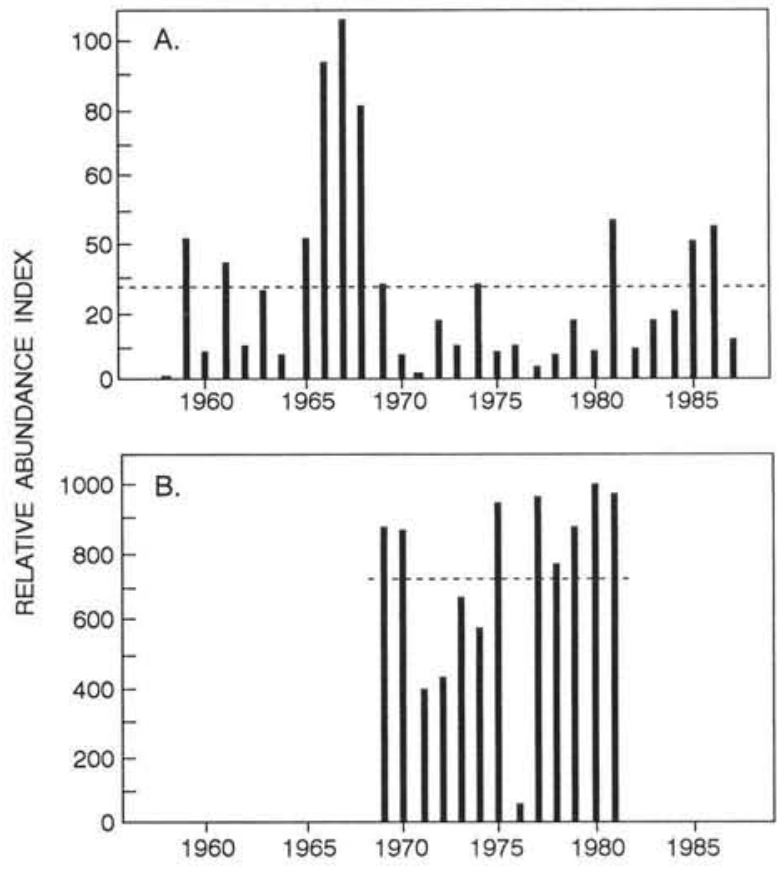

Fig. 9. Anchoa mitchilli. Indices of relative abundance of bay anchovy in Chesapeake Bay. (A) Maryland Department of Natural Resources beach seine survey data (MD DNR 1990). Index values are mean numbers per seine haul. Horizontal line is the $28 \mathrm{yr}$ mean index value of 26.7. (B) Academy of Natural Sciences of Philadelphia trawl survey data from mid Chesapeake Bay (Horwitz 1987). Data are numbers per $30 \mathrm{~min}$ tow of a $7.6 \mathrm{~m}$ semi-balloon trawl. Horizontal line is the 13 yr mean index value of 708

Since much of the annual variation in YOY and total abundance is attributable to recruitment fluctuations, the data in Fig. 9B may not demonstrate fully the annual variability in abundance.

Bay anchovy is a short-lived and essentially annual species in Chesapeake Bay. As such, interannual changes in its abundance, when they occur, do so as a consequence of recruitment fluctuations. Our results demonstrated that YOY and age 1 anchovy dominate the population. A single failed year-class could dramatically reduce bay anchovy abundance. Conversely, strong recruitment could dramatically increase it. Three surveys all indicated low bay anchovy abundance in Chesapeake Bay during 2 years, 1971 and 1976 (Wojcik \& Austin 1982, Horwitz 1987, MD DNR 1990), but concordant high abundances occurred only during 1981.

\section{Age and growth}

Bay anchovy maintains fast growth throughout its short lifespan (Figs. 5, 6 \& 7) and thus approaches 
Table 6. Von Bertalanffy growth parameters $\left(L_{\infty}, K\right)$ and natural mortality estimates $(M)$ reported for 9 engraulid species, including bay anchovy

\begin{tabular}{|c|c|c|c|c|}
\hline Species & $L_{\infty}(\mathrm{mm})$ & K & $M$ & Source \\
\hline Stolothrissa tanganicae & 89 & 2.65 & 5.2 & Coulter (1977) \\
\hline Cetengraulis mysticetus & 180 & 1.99 & 2.4 & Bayliff (1967) \\
\hline Engraulis anchoita & 232 & 0.27 & 1.42 & Bayliff (1967) \\
\hline E. anchoita & 173 & 0.72 & 0.90 & Brandhorst et al. (1974) \\
\hline E. capensis & 121 & 0.97 & - & Melo (1984) \\
\hline E. encrasicolus & 149 & 1.13 & 1.80 & Bayliff (1967) \\
\hline E. encrasicolus & 168 & 0.32 & - & Erkoyuncu \& Ozdamar (1989) \\
\hline E. encrasicolus & 191 & 0.35 & - & Morales-Nin \& Pertierra (1990) \\
\hline E. japonicus & 177 & 1.80 & 1.63 & Bayliff (1967) \\
\hline E. mordax & 164 & 0.45 & 1.70 & Bayliff (1967) \\
\hline E. ringens & 170 & 1.40 & 1.00 & Bayliff (1967) \\
\hline E. ringens & 150 & 1.70 & 1.52 & Boerema et al. (1965) \\
\hline E. ringens & 202 & 0.39 & - & $\begin{array}{l}\text { Morales-Nin (1989) (in Morales- } \\
\text { Nin \& Pertierra 1990) }\end{array}$ \\
\hline Anchoa mitchilli & $107.0-138.0$ & $0.21-0.36$ & $2.19-2.95$ & Present study \\
\hline
\end{tabular}

its asymptotic length $\left(L_{\infty}\right)$ at a relatively slow rate. It never survives long enough to reach the estimated $L_{\infty}$ ( $=107.0$ to $138.0 \mathrm{~mm}$ FL). The largest bay anchovy that we have observed from Chesapeake Bay was $105 \mathrm{~mm}$ TL (95 mm FL) and reports of fish longer than $100 \mathrm{~mm}$ TL. (91 mm FL) are rare.

Reported von Bertalanffy growth parameters of anchovy species are highly variable both within and among species. Our estimated values of $K$ for bay anchovy are low compared to most engraulids (Table 6), although 3 species, Engraulis anchoita, E. encrasicolus and $E$. ringens, have reported $K$ values similar to our estimate for bay anchovy. However, in each of those cases, higher estimates also have been reported. The remaining $K$ estimates, except for $E$. mordax, were much higher than the estimate for bay anchovy, indicating that most growth of those species is completed early in life with subsequent sharp declines in growth-rate potential as maximum sizes are approached.

Of our 3 von Bertalanffy models, the 2 based upon mean back-calculated length data (Models A and C, Table 4) described bay anchovy growth best, in part because they incorporated individual growth histories. Sampling biases could have influenced the fit of the growth model to observed length-at-age data because gear selectivity is a function of the length of anchovy at the time they were caught, not their length at earlier ages. A potential source of bias in the back-calculation approach could have arisen because growth histories of survivors, not average anchovy, were used. However, the similarity of the von Bertalanffy parameters derived from observed length-at-age and back-calculation data suggests that errors in estimating length-atage based upon either model are small. Although the
3 models (Table 4) may adequately describe bay anchovy growth, we believe that the seasonally oscillating version, based upon mean back-calculated length data, provides the most accurate estimates of bay anchovy lengths-at-age.

Our length-based von Bertalanffy growth models differ markedly from one reported for Delaware Bay anchovy (PSEG 1984) which had comparatively low $L_{\infty}$ $(68.44 \mathrm{~mm})$, and very high $K(2.63)$ and $t_{0}(-0.012)$ values. The PSEG (1984) model poorly described observed lengths-at-age of bay anchovy from either Chesapeake Bay or Delaware Bay. It was fitted to observed mean length-at-age data and forced to pass through a $2.0 \mathrm{~mm}$ expected length-at-hatch. The forced fit led to the high $K$ estimate and a predicted mean length at age 1 of Delaware Bay bay anchovy $>10 \mathrm{~mm}$ longer than our estimate for Chesapeake Bay. The low $L_{\infty}$ reported by PSEG (1984) primarily was a consequence of small estimated mean length at age 3 .

Stevenson (1958) estimated growth from modal length progression of bay anchovy in Delaware Bay. He found that modal length of YOY was $15 \mathrm{~mm}$ in July, $25 \mathrm{~mm}$ in August and $39 \mathrm{~mm}$ in October. Growth rates computed from those modal lengths were $0.33 \mathrm{~mm} \mathrm{~d}^{-1}$ (July to August) and $0.23 \mathrm{~mm} \mathrm{~d}^{-1}$ (August to October). These rates are low compared to other reported larval and early juvenile growth rates of bay anchovy, which ranged from 0.43 to $0.56 \mathrm{~mm} \mathrm{~d}^{-1}$ (Leak \& Houde 1987), 0.24 to $1.11 \mathrm{~mm} \mathrm{~d}^{-1}$ (Fives et al. 1986), and $>0.50 \mathrm{~mm}$ $\mathrm{d}^{-1}$ (Castro \& Cowen 1991). Our estimated mean growth rate of YOY anchovy, based upon the mean back-calculated length at fall mark 1 and an assumed mean hatching date of 15 July (Dalton 1987), was $0.41 \mathrm{~mm} \mathrm{~d}^{-1}$. This estimate compares favorably to YOY growth rates estimated from daily otolith increments of 
mid Chesapeake Bay anchovy in 1986 and 1987, which were $0.47 \mathrm{~mm} \mathrm{~d}^{-1}$ in each year (Zastrow et al. 1991). Our growth rates, estimated from progression of length modes of trawl-caught YOY anchovy, were much lower, averaging 0.33 and $0.20 \mathrm{~mm} \mathrm{~d}^{-1}$ in 1986 and 1987 , respectively, and were similar to those reported by Stevenson (1958). The modal progression method yields lower growth rates because the relatively rapid larval-stage growth is not represented.

\section{Mortality}

Catch-curve analysis indicated that annual mortality rates of bay anchovy in Chesapeake Bay range from 89 to $95 \%$ for fully recruited juveniles and adults. These mortality rates lie in the upper part of the range of mortality rates reported for engraulid species. Reported instantaneous natural mortality rates of engraulids range from 0.90 to $5.20\left(59\right.$ to $>99 \% \mathrm{yr}^{-1}$ ) and appear to be inversely related to their respective $L_{\infty}$ estimates (Table 6).

For comparison with catch curve estimates of mortality, we applied 4 procedures dependent upon life history relationships. Each gave lower estimates than the catch-curve analyses (Table 5). An estimate from Pauly's (1980) relationship, which we derived by substituting into his equation our von Bertalanffy model parameters, $L_{\infty}=129.3 \mathrm{~mm}$ FL $(=144.8 \mathrm{~mm} \mathrm{TL})$ and $K=0.23$, and a mean environmental temperature of $15^{\circ} \mathrm{C}$, yielded an estimated instantaneous mortality rate of $Z=0.63\left(47 \% \mathrm{yr}^{-1}\right)$, a rate probably too low for such a short-lived species. Hoenig's (1983) longevitybased relationship, assuming $3.0 \mathrm{yr}$ to be maximum age, gave an instantaneous rate of $Z=1.42\left(76 \% \mathrm{yr}^{-1}\right)$. Ssentongo \& Larkin's (1973) relationship, assuming $0.72 \mathrm{yr}$ is mean age in the catch and $0.20 \mathrm{yr}$ is age at first capture, based upon our CPUE statistics, gives an instantaneous mortality rate of $Z=1.09\left(66 \% \mathrm{yr}^{-1}\right)$. Roff's (1984) relationship, with $L_{\infty}=129.3 \mathrm{~mm}$ FL, $K=$ 0.23 , and length at maturity $40 \mathrm{~mm}$ FL (Zastrow et al. 1991), gave $Z=1.54\left(79 \% \mathrm{yr}^{-1}\right)$.

Our catch-curve estimates, which are based upon actual catch-at-age data, probably provide the best estimates of bay anchovy mortality. If annual mortality is in the range 89 to $95 \%$, the predicted age structure of the mid Chesapeake Bay anchovy population $(>30 \mathrm{~d}$ posthatch) in late summer will be 88.8 to $94.8 \%$ age $0+$, 5.0 to $9.9 \%$ age $1+, 0.3$ to $1.1 \%$, age $2+$ and $\leq 0.1 \%$ age $3+$. If vulnerability to the trawl of larger and older anchovy declines, it is possible that mortality rates may have been overestimated in the catch-curve analysis.

Bay anchovy contends with its high mortality rate by maturing early and having high reproductive capacity. Zastrow et al. (1991) found that most adult females in

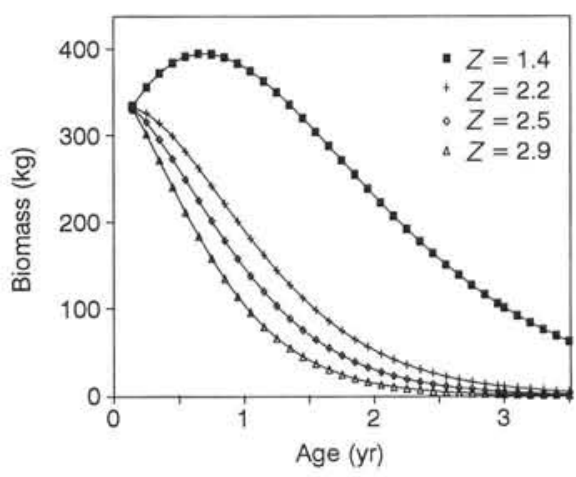

Fig. 10. Anchoa mitchilli. Simulated biomass of an annual cohort of bay anchovy with an initial abundance of 1 million individuals, subjected to different mortality rates. Weights-atage were estimated from the weight form of the von Bertalanffy model. The simulations were carried out for post-metamorphosis juvenile and adult anchovy, starting at age $50 \mathrm{~d}$

$$
\text { (i.e. }>0.14 \mathrm{yr} \text { ) }
$$

mid Chesapeake Bay spawned approximately 700 eggs $\mathrm{g}^{-1}$ body weight each night during the $50 \mathrm{~d}$ peak period of the 1986-1987 spawning seasons. Applying our length-at-age data, it is apparent that more than $92 \%$ of the spawning females were age 1 .

The high reproductive effort and high mortality rates of bay anchovy indicate that maximum biomass will be attained in the late postlarval or juvenile stage. Simulating the trend in numbers and the growth in weight of a hypothetical cohort $>50 \mathrm{~d}$ after hatching indicated the age at which biomass is maximum (Fig. 10). It ranged from $<0.14$ to $0.75 \mathrm{yr}$, depending on the mortality rate used in the simulation. Luo \& Brandt (1993), applying a bioenergetics model, estimated that biomass of bay anchovy in Chesapeake Bay peaks during November, when YOY individuals were about $0.3 \mathrm{yr}$ mean age. Our estimated mortality rates from catch curves indicate maximum biomass at younger ages $(<0.14 \mathrm{yr})$, when anchovy mean length is $<30 \mathrm{~mm}$ FL. Our simulation results suggest that biomass maximum occurs in late summer, when the population is dominated by newly recruited juveniles and metamorphosing larvae. If the lower mortality rates derived from the life history procedures are correct, our simulations using those values still predict maximum biomass well before 1 yr of age.

Acknowledgements. We thank E. Chesney for contributing to the design and implementation of the field program, C. Zastrow for information and data on bay anchovy reproductive biology, and L. Morin for making available information on otolith daily increments. S. Leach and E. Rutherford helped with the seasonally oscillating von Bertalanffy model. F. Younger provided illustrating assistance and L. Fernandez prepared the manuscript. Research was supported by NOAA, Department of Commerce, Maryland Sea Grants R/F-55 and R/F-65, and NSF Grants OCE8701304 and OCE9203307. 


\section{LITERATURE CITED}

Bagenal, T. B., Tesch, F. W. (1978). Age and growth. In: Bagenal, T. B. (ed.) Methods for assessment of fish production in fresh waters, 3rd edn. Blackwell Scientific Publ., Oxford, p. 101-136

Baird, D., Ulanowicz, R. E. (1989). An energy flow network for the Chesapeake Bay. Ecol. Monogr. 59: 329-364

Bayliff, W. H. (1967). Growth, mortality, and exploitation of the Engraulidae, with special reference to the anchoveta, Cetengraulis mysticetus, and the colorado, Anchoa naso, in the eastern Pacific Ocean. Bull. Inter-Am. Trop. Tuna Comm. 12: 365-432

Beamish, R. J., McFarlane, G, A. (1983). The forgotten requirement for age validation in fisheries biology. Trans. Am. Fish. Soc. 112: 735-743

Brandhorst, W., Castello, J. P., Cousseau, M. B., Capezzani, D. A. (1974). Evaluation of anchovy resources (Engraulis anchoita) in offshore Argentina and Uruguay. VIII. Spawning, growth and population structure. Physis Secc. A Oceanos Sus Org. (A)33: 37-58

Boerema, L. K., Saetersdal, G., Tsukayama, I., Valdivia, J. E., Alegre, B. (1965). Report on the effects of fishing on the Peruvian stock of anchovy. FAO Fish. Tech. Pap. 55: 1-44

Carlander, K. D. (1981). Caution on the use of the regression method of back-calculating lengths from scale measurements. Fisheries 6(1): 2-4

Castro, L. R., Cowen, R. K. (1991). Environmental factors affecting the early life history of bay anchovy Anchoa mitchilli in Great South Bay, New York. Mar. Ecol. Prog. Ser. 76: 235-247

Coulter, G. W. (1977). Approaches to estimating fish biomass and potential yield in Lake Tanganyika. J. Fish Biol. 11: 393-408

Dalton, P. D. (1987). Ecology of bay anchovy Anchoa mitchilli eggs and larvae in the mid-Chesapeake Bay. M.Sc. thesis, Univ. Maryland, College Park

Erkoyuncu, I., Ozdamar, E. (1989). Estimation of the age, size and sex composition and growth parameters of anchovy, Engraulis encrasicolus (L.) in the Black Sea. Fish. Res. 7 : 241-247

Fitch, J. E. (1951). Age composition of the southern California catch of Pacific mackerel 1939-40 through 1950-51. Calif. Fish Game Fish. Bull. 101: 7-34

Fives, J. M., Warlen, S. M., Hoss, D. E. (1986). Aging and growth of larval bay anchovy, Anchoa mitchilli, from the Newport River estuary, North Carolina. Estuaries 9: 362-367

Francis, R. I. C. C. (1990). Back-calculation of fish length: a critical review. J. Fish Biol. 36: 883-902

Hanumara, R. C., Hoenig, N. A. (1987). An empirical comparison of a fit of linear and non-linear models for seasonal growth in fish. Fish. Res. 5: 359-381

Hartman, K. J. (1993). Striped bass, bluefish, and weakfish in the Chesapeake Bay: energetics, trophic linkages, and bioenergetics model applications. Ph.D. dissertation, Univ. Maryland, College Park

Hildebrand, S. F. (1963). Fishes of the Western North Atlantic, Part 3, Memoir I. Sears Foundation for Marine Research, New Haven

Hildebrand, S. F., Schroeder, W. C. (1928). Fishes of Chesapeake Bay. U.S. Bur. Fish. Bull. 43

Hoenig, J. M. (1983), Empirical use of longevity data to estimate mortality rates. Fish. Bull. U.S. 82; 898-903

Hoese, H. D., Moore, R. H. (1977). Fishes of the Gulf of Mexico: Texas, Louisiana and adjacent waters. Texas A\&M Univ. Press, College Station
Homer, M., Boynton, W. (1978). Stomach analysis of fish collected in the Calvert Cliffs region, Chesapeake Bay, 1977. Final Report to Maryland Dept of Natural Resources, Power Plant Siting Program, Annapolis, Ref. No. [UMCEES]CBL 78-154

Horwitz, R. J. (1987). Fish. In: Heck, K. L. (ed.) Ecological studies in the middle reach of Chesapeake Bay. Lecture notes on coastal and estuarine studies, Vol. 23, Chap. 6. Springer-Verlag, Berlin, p. 167-224

Houde, E. D., Zastrow, C. E. (1991). Bay anchovy. In: Funderburk, S. L., Mihursky, J. A., Jordan, S. J., Riley, D. (eds.) Habitat requirements for Chesapeake Bay living resources, 2nd edn. Living Resources Subcommittee, Chesapeake Bay Program, Annapolis, MD, p. 8.1-8.14

Klebasko, M. J. (1991). Feeding ecology and daily ration of bay anchovy (Anchoa mitchilli) in the mid-Chesapeake Bay. M.Sc. thesis, Univ. of Maryland, College Park

Leak, J. C., Houde, E. D. (1987). Cohort growth and survival of bay anchovy Anchoa mitchilli larvae in Biscayne Bay, Florida. Mar. Ecol. Prog. Ser. 37: 109-122

Luo, J., Brandt, S. B. (1993). Bay anchovy production and consumption in mid-Chesapeake Bay based on a bioenergetics model and acoustic measures of fish abundance. Mar. Ecol. Prog. Ser. 98: 223-236

Luo, J., Musick, J. (1991). Reproductive biology of the bay anchovy in Chesapeake Bay. Trans. Am. Fish. Soc, 120: $701-710$

MD DNR (1990). Investigation of striped bass in Chesapeake Bay. U.S. Fish Wildlife Service, Federal Aid Project F.42. R.2 Annual Report. Maryland Dept of Natural Resources, Annapolis

Melo, Y. C. (1984). Age studies on anchovy Engraulis capensis Gilchrist off South West Africa. S. Afr. J. mar. Sci. 2: 19-31

Merriner, J. V. (1975). Food habits of the weakfish, Cynoscion regalis, in North Carolina waters. Chesapeake Sci. 16: $74-76$

Monaco, M. E., Czapla, T. E., Nelson, D. M., Pattelo, M. E. (1989). Distribution and abundance of fishes and invertebrates in Texas estuaries. U.S. Dept of Commerce, National Oceanic and Atmospheric Administration, Estuarine Living Marine Resources Project, Rockville, MD

Morales-Nin, B. (1989). Age and growth of the southern stock of Peruvian anchoveta based on otolith microstructures and length-frequency analysis. International Center for Living Aquatic Resources Management, Manila, Philippines. Proc. int. Center Living Aquat. Resour. Mgmt (ICLARM) Conf. 18: 179-188

Morales-Nin, B., Pertierra, J. P. (1990). Growth rates of the anchovy Engraulis encrasicolus and the sardine Sardina pilchardus in the Northwestern Mediterranean Sea. Mar. Biol. 197: 349-356

Morton, T. (1989). Species profiles: life histories and environmental requirements of coastal fishes and invertebrates (Mid-Atlantic) - bay anchovy. Biol. Rep. U.S. Fish Wildl. Serv. 82(11.97): 1-13

Pauly, D. (1980). On the interrelationships between natural mortality, growth parameters, and mean environmental temperature in 175 fish stocks. J. Cons. int. Explor. Mer 39: 175-192

Pauly, D., Gaschutz, G. (1979). A simple method for fitting oscillating length growth data, with a program for pocket calculators. Comm. Meet. int. Counc. Explor. Sea C.M.ICES 1979/G:24: 1-26

PSEG (1984). Bay anchovy (Anchoa mitchilli): a synthesis of information of natural history, with reference to occurrence in the Delaware River and estuary and involvement 
with the Salem Generating Station, Appendix XII, bay anchovy. Salem Generating Station 316(b) Demonstration. Public Service Electric and Gas Company, Newark, NJ

Richards, S. W. (1976). Age, growth, and food of bluefish (Pomatomus saltatrix) from east-central Long Island Sound from July through November 1975. Trans. Am. Fish. Soc. 105: 523-525

Ricker, W. E. (1975). Computation and interpretation of biological statistics of fish populations. Bull. Fish. Res. Bd Can. 191: 1-382

Roff, D. A. (1984). The evaluation of life history parameters in teleosts. Can. J. Fish. Aquat. Sci. 41: 989-1000

Schaefer, R. H. (1970). Feeding habits of striped bass, Morone saxatilis, from the surf waters of Long Island. N.Y. Fish Game J. 17: 1-17

Ssentongo, G. W., Larkin, P. A. (1973). Some simple methods of estimating mortality rates of exploited fish populations. J. Fish. Res. Bd Can. 30: 695-698

Stevenson, R. A. Jr (1958). The biology of the anchovies, Anchoa mitchilli mitchilli Cuvier and Valenciennes 1848

This article was presented by K. R. Tenore (Senior Editorial Advisor), Solomons, Maryland, USA and Anchoa hepsetus hepsetus Linnaeus 1758 in Delaware Bay. M.Sc. thesis, Univ. of Delaware, Newark

Vazquez, A. V. (1989). Energetics, trophic relationships and chemical composition of bay anchovy, Anchoa mitchilli, in the Chesapeake Bay. M.Sc. thesis, Univ. of Maryland, College Park

Vouglitois, J. J., Able, K. W., Kurtz, R. J., Tighe, K. A. (1987). Life history and population dynamics of the bay anchovy in New Jersey. Trans. Am. Fish. Soc. 116: 141-153

Wojcik, F. J., Austin, H. M. (1982). Estimates of abundance VIMS small fish trawl survey - York and Rappahannock Rivers, 1955 to 1982. Report to the EPA as part of the Chesapeake Bay Program. Virginia Institute of Marine Sciences, Gloucester Point

Zar, J. H. (1974). Biostatistical analysis. Prentice Hall, Inc., Englewood Cliffs, NJ

Zastrow, C. E., Houde, E. D., Morin, L. G. (1991). Spawning, fecundity, hatch-date frequency and young-of-the-year growth of bay anchovy Anchoa mitchilli in mid-Chesapeake Bay. Mar. Ecol. Prog. Ser. 73: 161-171

Manuscript first received: August 9, 1993

Revised version accepted: August 24, 1994 